Neža Zajc

\title{
Sveti Maksim Grek (cca. 1470-1556): med rokopisi, knjigami in knjižnicami $v$ zgodnjerenesančnem obdobju
}

Posvečeno spominu liturgika in skrbnika ljubljanske Semeniške knjižnice Marijana Smolika

Maksim Grek je bil grški učenjak, ki je svoje življenje posvetil besedni umetnosti in umetnosti knjižnega hranjenja in knjižničnega ohranjanja ter varovanja zapisane človeške modrosti. Kljub težki življenjski usodi je vedno znova razumno doumeval, da je tovrstna dejavnost tista, ki zmore človeka ohranjati ne le duhovno budnega, temveč navsezadnje tudi vedrega in zdravega.

Slika 1: Ikona: sveti Maksim Grek, Arta

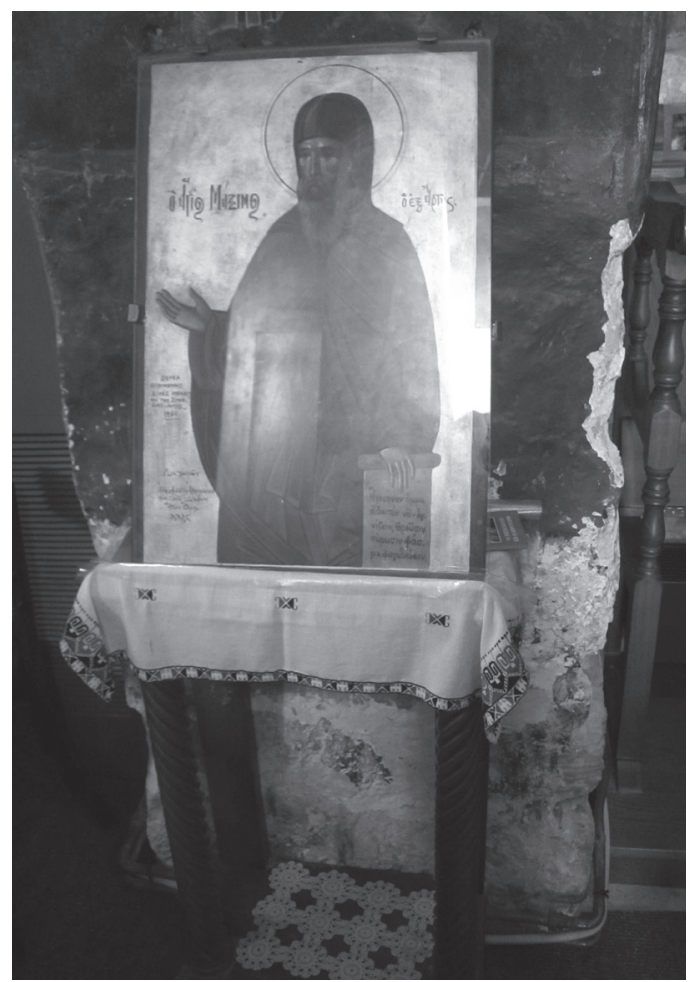


Rodil se je kot Mihael (gr. Mihail) Trivolis okoli leta 1470 v grškomakedonskem mestecu Arta, ${ }^{1}$ blizu meje nekdanjega bizantinskega cesarstva in današnje Albanije. Že v zgodnji mladosti se je pobliže srečal s tako imenovano knjižno modrostjo, saj je njegov stric Demetrij Trivolis imel doma veliko osebno knjižnico. Leta 1491 ga je maja ali junija v Arti obiskal Joannis Laskaris (cca. 14451535) zaradi zbiranja rokopisnih knjig za biblioteko Lorenza Medičejskega (14491492). To lahko sklepamo po pismu, ki ga je J. Laskaris pisal iz Konstantinopla 10. julija 1491 Demetriju Halkondilu. ${ }^{2}$ Demetrij Trivolis je gojil stike z grškimi učenjaki, predvsem s tistimi z bližnjega Krfa in Krete. Med njimi so bili kardinal Bessarion, ki je pozneje ustanovil prvo beneško javno knjižnico, danes znano kot »Marciana«, Markos Musuros, Demetrij Halkokondil, Manuel Hrisoloras in člani družine Moshos (oče Joannis in dva sinova, Georgij in Demetrij). Ko je bilo Mihaelu dvajset let, je leta 1490 odpotoval na $\mathrm{Krf}^{3}{ }^{3}$ kjer je navezal prijateljske stike predvsem z Georgijem Moshosom, ki je tam študiral medicino in retoriko, ${ }^{4}$ ter Markom Musurom, ki je že tedaj pisal poetične spise v verzih. Na Krfu se je leta 1491 Mihael Trivolis komaj enaindvajsetleten udeležil volitev: kandidiral je za mesto v svetu Velikega senata, ki ga je ustanovila Beneška republika, da bi vzpostavila delni red po turškem zavzetju otoka. ${ }^{5} \mathrm{~S}$ Krfa so se mladi grški misleci skupaj namenili v severno Italijo, pot jih je vodila prek Jadranskega morja in hrvaških otokov. Leta 1492 je bil Mihael Trivolis že v Firencah (nekoč romarskem mestu, posvečenem Marijinemu Oznanjenju), kjer je bival pri Joannisu Laskarisu. V njegovem florentinskem stanovanju je Mihael spoznal Alda Manuzia, ki je tedaj tehtal možnosti in pogoje za ustanovitev tiskarne prav v Firencah. Mihael Trivolis se je v Firencah družil z intelektualci, ki so se ukvarjali s prevajanjem grških filozofskih traktatov v latinščino, med katerimi so bili tudi Marcilio Ficino (tedaj vodilni prevajalec Dionizija Areopagita), Cristophoro Landino (med drugim tudi komentator Danteja Alighierija) ${ }^{6}$ ter filozof Angelo Poliziano, ki je bil tudi Mihaelov profesor. ${ }^{7}$ Mladi Mihael Trivolis naj bi bil celo povabljen, da skupaj z omenjenimi misleci uredi in sestavi nabor knjig, ki naj bi jih imela družinska knjižnica znamenite florentinske rodbine Medičejcev; vendar je ta načrt ostal neuresničen. Učil se je lingvističnega in revizorskega dela $\mathrm{z}$ besedili pri Joannisu Laskarisu, izuril pa se je tudi v specifičnem ravnanju in delu $\mathrm{z}$ rokopisi, ki jih je najprej prepisoval ter opremljal z ustreznimi pravili, inicialkami in okrasi na marginalijah.

Mihael Trivolis je za Joannisa Laskarisa dvakrat prepisal rokopisno knjigo Geoponika ${ }^{8}$ (knjiga je združevala botanično in naravoslovno znanje z

\footnotetext{
Denissoff, Maxime le Grec, 129, 137-138.

Piccolomini, Aggiunte, 152.

Ibid., 139.

Ibid., 143.

Ibid., 144-145.

Garzaniti, Michele Trivolis/Massimo il Greco, 343.

Denissoff, Maxim le Grec, 152.

8 Denissoff, Maxime le Grec, 224.
} 
nekaterimi ljudskimi modrostmi in izročili, ki jih je bilo mogoče pojasniti ne le $\mathrm{z}$ vraževerji, ampak tudi z vzhodno krščansko molitveno tradicijo), kot je zabeleženo v rokopisu, ki ga danes hrani Narodna knjižnica v Parizu. Dejstvo, da je poudaril svoj podpis $z$ rdečim ter zraven dodal notico o dvakratnem prepisu na prošnjo Joannisa Laskarisa s črnim črnilom, priča, da se je Mihael Trivolis tedaj že močno zavedal problematike, ki je zadevala vprašanje avtorstva. Obenem je tak zaznamek moč razumeti tudi kot odraz njegovega zavedanja pomena posameznikovega dela in slehernikovega obstoja, kar je bilo v sozvočju z naraščajočim zgodnjerenesančnim izpostavljanjem vloge individualnega deleža $v$ soustvarjanju zgodovinskega procesa. Usoda rokopisne knjige Geoponika pa je bila naslednja: najprej je bila v lasti Joannisa Laskarisa, ki jo je ta po vsej verjetnosti še za časa svojega življenja v Italiji ali Franciji podaril italijanskemu pesniku, diplomatu in filologu Andrei Naugeriju (14831529). ${ }^{9}$ Sodeč po kratki grški notici Mattea Devarija v knjigi, se je Geoponika znašla v knjižnici kardinala Nicola Ridolfija. Po njegovi smrti leta 1550 je delo postalo last knjižne zbirke francoskega maršala Pierra Strozzija in tam ostalo vse do leta 1558. Kasneje je Geoponika prešla v francosko knjižnico Katarine Medičejske, kjer je bila do leta 1589. Od leta 1599 dalje je bila knjižnica Katarine Medičejske spremenjena v novo francosko kraljevo knjižnico, kjer je bilo leta 1604 to delo katalogizirano; tam se nahaja še dandanes, saj je bila kraljeva knjižnica preimenovana v Narodno knjižnico v Parizu. ${ }^{10}$

Mihael Trivolis je prepisal tudi dve rokopisni knjigi, in sicer Strabonovo Geografijo ter Judovske vojne Jožefa Flavija, prepis obeh danes hrani Apostolska biblioteka v Vatikanu. Pod prepis Strabonove Geografije se je Mihael Trivolis kot prepisovalec podpisal, v rokopisu Jožefa Flavija pa naletimo na povsem enake topografske izraze, kot jih je pozneje Maksim Grek vključeval v svoje rokopisne spise, ko je opisoval lastno življenjsko pot (na primer: »v deželah pod Alpami in do (reke) Gadira«). V njegovi lasti je bila tudi kopija rokopisne knjige De materia medica Dioskorida (natisnjena »Aldina «, 1. 1500: »Pedacii Dioscoridis De materia medica libri sex. Venetiis, Apud Aldum, Mense Iulio MID «), ena najbolj dragoceno ilustriranih grških knjig preteklosti, ki jo je po vsej verjetnosti prvi prepisal njegov stric Demetrij Trivolis še na Krfu, potem jo je nekaj časa hranil Georgij Moshos, nato pa Demetrijev nečak in Mihaelov daljni bratranec Antonio Eparque.

$\mathrm{V}$ občudovanju svojih grških kolegov, predvsem Marka Musura in Demetrija Moshosa, ki sta bila tudi pesniško nadarjena, je Mihael Trivolis sprostil tudi svojo poetično ustvarjalnost. Prepis rokopisne knjige, kjer so bila zbrani komentarji grških neoplatonističnih mislecev Siriana (komentatorja Aristotelove Metafizike, umrl leta 437), Sopatra ${ }^{11}$ (sofista in neoplatonista

9 Fonkič, Grečeskie rukopisi i dokumenty, 79.

10 Ojkonomides, Actes de Kastamonitou, 30, tabela I.

11 Tega misleca je iskal za knjižnico Lorenza Magnifica Medici J. Laskaris (Denissoff, Maxim k le Grec, 128). 
iz Apameje, umrl ok. 370), Hermogena (iz Tarza, antičnega filozofa in retorja) in Marcelina iz Kartagine (krščanskega svetnika, umrl ok. 314), je tako opremil z lastnimi verzifikacijami v obliki monokondolionov ${ }^{12}$ na marginalijah rokopisa. Čeprav je Markos Musuros postal prvi profesor grščine na Univerzi v Padovi v Italiji ter cenzor za grške prvotiske v Benetkah in je pesnik Demetrij Moshos poučeval grščino v Benetkah in Ferrari, pa je Mihael Trivolis zavrnil ponudbo, da bi na povabilo Urcea Codra začel poučevati na Univerzi v Bologni. ${ }^{13}$ Vse to se je zgodilo potem, ko je med člani t. i. grške diaspore že postalo znano, da Mihael odlično pojasnjuje težavnosti grškega jezika, saj je med letoma 1495 in 1499 dvakrat bival na gradu Mirandola, kjer je poučeval grščino nečaka slavnega Giovannija Pica della Mirandole ${ }^{14}$ in mu pomagal pri prevodu grškega spisa neznanega avtorja De Monarchia Dei. ${ }^{15}$ Zdi se, da je med njunim druženjem nastala plodna osnova za kritičen odnos do tedaj obujenega neoplatonizma, saj je nečak Gianfancesco kasneje izražal protiaristoteljanske filozofske poglede. ${ }^{16} \mathrm{Na}$ gradu Mirandola, kjer se je družil tudi z Joannisom Grigoropulom in Demetrijem Moshosom, pa je čas pogosto uhajal ob opravilih, ki »niso pripomogla k duhovnemu napredovanju«, kot se je Mihael izrazil v pismu prijatelju Scipionu »Fortiguerri«-Carteromahu. ${ }^{17}$ Tudi Joannisu Grigoropulu je pisal z Mirandole in ga prosil, da naj stori vse, kar je v njegovih močeh, da bi mu našel delo v tiskarski delavnici Alda Manuzia v Benetkah, kjer so do takrat že natisnili grški Psalter (leta 1494). Načrtovana pa je bil tudi trojezična Biblija (v hebrejščini, latinščini in grščini), ${ }^{18}$ o kateri je pisal Aldo Manuzio v pismu Conradu Celtisu. ${ }^{19}$

Kljub svojemu navduševanju nad mestom »Florencija«, kot ga je imenoval v svojih rokopisih in ga opisal kot najbolj čudovito mesto, kar jih je kdaj koli videl v Italiji, in ne glede na to, da je pod vplivom pridig Girolama Savonarole celo začasno stopil v dominikanski samostan Svetega Marka (ne da bi sprejel meniški red), pa si je Mihael Trivolis želel predvsem poglobljenega dela, ki mu je bilo v Italiji omogočeno zgolj v tiskarni Alda Manuzia v Benetkah. Tam je spoznal tudi nekatere druge grške učenjake, topografe in filologe; med njimi so bili Zaharias Kalliergis, Nikolaos Sofianos ${ }^{20}$ in Nikolaos Vlastos, pa tudi italijanski filolog Giovanni Crastone in beneški zgodovinar Pietro Bembo. Aldo Manuzio je lični črkopis-pisavo Mihaela Trivolisa celo izbral za natis (kot »drückvorlagen «) verzov Teokritovih Idil. ${ }^{21}$ Dodati je treba, da se je tedaj iz pripadnikov t. i. grške diaspore oblikovala v Benetkah prva grška pravoslavna

\footnotetext{
12 Speranzi, »Michele Trivoli e Giano Lascari«, 266, op. 23, 278, 280; Denissoff, Maxim le Grec, 136.

13 Dorez, Etudes Aldines, 323-326.

14 Denissoff, n. d., 233.

15 Prav tam, 231; Garzaniti, Biblejskie citaty, 161.

16 Več o tem gl. Schmitt, Gianfrancesco Pico della Mirandola.

17 De Nolhac, Les correspondants d'Aldes, 263.

18 Legrand, Bibliographie hellenique, 24.

19 Renouard, Annales, 388, 516.

20 Ševčenko, The Four World, 296.

21 Speranzi, »Michele Trivoli«, 282.
} 
občina ali skupnost grških priseljencev. Tudi sam Aldo Manuzio je načrtoval tisk grških liturgičnih knjig, kar pa se ni uresničilo (to je bil že drugi tovrstni poskus, po Kalliergisovem nerealiziranem poskusu v Rimu). ${ }^{22}$ Znano je tudi, da so v nekaj zadnjih desetletij 15. stoletja iz samostanov svete gore Atos in drugih grških svetih mest prinašali bizantinske bogoslužne rokopise in jih v severni Italiji poustvarjali ter s tem ohranjali njihovo vsebino neokrnjeno $\mathrm{v}$ obliki inkunabul.

Leta 1506 je Mihael Trivolis iz beneškega pristanišča zapustil italijanska tla in zdi se, da je imel pred seboj natančen cilj, odpotovati je na sveto goro Atos. Tam je vstopil v samostan Vatopedion, posvečen Marijinemu Oznanjenju, sprejel meniški stan in postal vatopedski menih Maksim. Na Sveti gori so prepoznali in cenili njegovo znanje o knjižnih in rokopisnih zadevah ter mu zaupali prepis nekaterih najbolj dragocenih in starih dokumentov, ki so bili odločilni za vprašanja o samostanskih posestih. Tako je na primer prepisal listino iz 11. stoletja, ki je določala medsamostansko območje in lastnino med samostanoma Kastamonit in Zograf. ${ }^{23}$ Med bivanjem v Vatopediju se je menih Maksim srečal s slovanskimi rokopisi. Njegovo delo je tako vključevalo branje in prevajanje rokopisov ter preverjanje besedil na osnovi primerjalne analize z grškimi originali. Ohranjene so njegove marginalije v redkem grškem izvodu žitja (hagiografije) Klimenta Ohridskega in liturgične službe temu svetniku v grškem Menologiju (njegovo življenje je znano predvsem po bolgarskem cerkvenoslovanskem izvodu žitja izpod peresa Teofilakta Bolgarskega). ${ }^{24}$

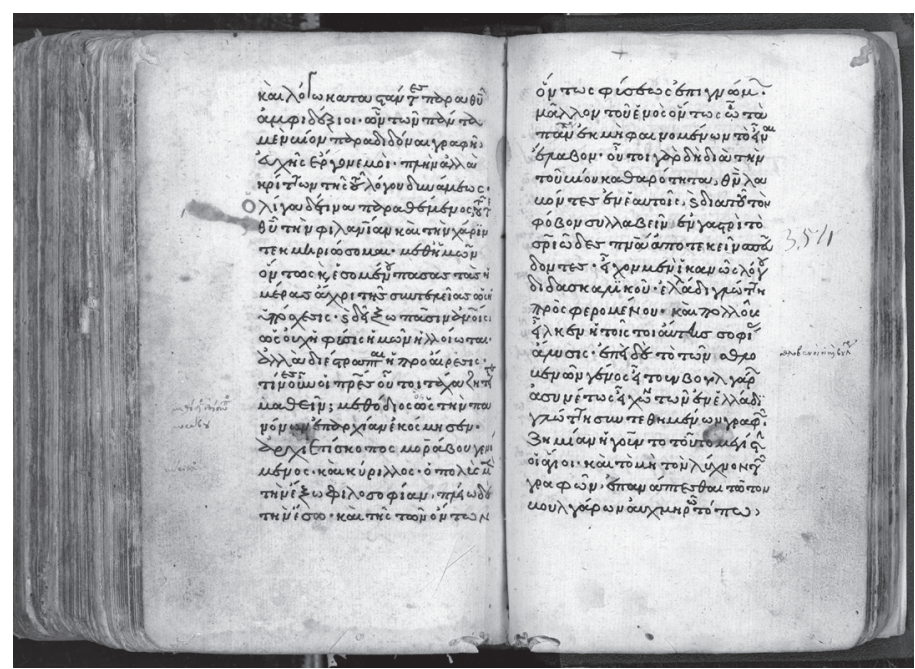

Slika 2: Rokopis grškega Žitja in liturgične službe sv. Klimentu Ohridskemu, marginalije meniha Maksima: sveta gora Atos, samostan Vatopedion

22 Layton, "Notes on Some Printers «, 120, op. 4.

23 Prep. Maksim Grek, Sočinenija, 108.

24 Koneski, Kniga za Kliment, 28-29. 
Poleg tega je menih Maksim tesno sodeloval s patriarhom Nifontom II., bil je njegov učenec. Spremljal ga je celo izven svete gore Atos v moldavsko-vlaške dežele na nekakšne pravoslavne misije, kjer je po vsej verjetnosti uporabljal latinščino kot sporazumevalni jezik. To je bilo tudi sicer značilno za tedanjo srednjeevropsko humanistično kulturo. V samostanu Vatopedion je Maksim ustvarjal tudi verzificirana dela: liturgičnemu bizantinskemu glasbeniku Manuelu Korintskemu je napisal epigram, ${ }^{25}$ ob smrti patriarha Nifonta II. je zanj napisal biografski epigram in dva epitafa. ${ }^{26}$ Tovrstni biografsko hvalilni nagrobni govori $\mathrm{v}$ obliki verznih epigramov, ki so izhajali iz bizantinske patristične tradicije, naj bi tedaj predstavljali posebno zgodnjerenesančno humanistično literarno obliko, posebej značilno za vzhodnoevropske dežele; med drugim tudi slovenske. ${ }^{27} \mathrm{~V}$ mislih imamo literarno zapuščino Eneja Silvija Piccolominija, ki je dosegel, da so so se takrat humanistični žanri dotaknili tudi dvora zadnjega grofa Celjskega Ulrika Drugega (Johannes Rot je bil avtor nagrobnega biografskega govora ob smrti Ulrika II. Celjskega). ${ }^{28}$ Vatopedski menih Maksim je napisal tudi lastne bogoslužne ode, in sicer »Verze, posvečene mučeniku sv. Dimitriju « ${ }^{29}$ ter Veliki kanon Janezu Krstniku.

Leta 1516 je bil Maksim, ki ga takratni dokumenti že omenjajo kot »starca« (najvišjega duhovnega vodnika v pravoslavnem meništvu), izbran kot najustreznejši vatopedski menih, ki ga je prot samostana blagoslovil za pot v moskovsko Rusijo: ruski veliki knez Vasilij III. je namreč poslal na Sveto goro pismo s prošnjo, naj pošljejo v Rusijo prevajalca in korektorja liturgičnih knjig. Na potovanju, ki je trajalo poldrugo leto, se je Maksim učil slovanskega jezika, na poti so se ustavili v nekdanjem Konstantinoplu ter po vsej verjetnosti tudi v Benetkah. Čeprav je Aldo Manuzio leto prej umrl in je njegovo tiskarsko delavnico prevzel sin Paolo, je menih Maksim lahko pri starih grških znancih dobil nekatere grške liturgične prvotiske, morda pa tudi slovanske, saj se je leta 1518 tam začenjala prva faza tiskanja liturgičnih knjig za pravoslavne Slovane v tiskarni Božidarja in Vincenza Vukoviča. Slednje so hranjene v precejšnjem številu tudi v zbirki bogoslužnih prvotiskov Jerneja Kopitarja v rokopisnem oddelku Narodne univerzitetne knjižnice v Ljubljani.

V Moskvi so svetogorskega meniha Maksima poimenovali Maksim Grek. Takoj so ga v cerkvenih in dvornih krogih začeli izjemno ceniti zaradi filozofskega in teološkega znanja in meniških izkušenj. Kmalu je postal znan kot eden najmodrejših mož tistega časa, predvsem pa kot velik in strog poznavalec pravoslavne teologije. Takoj po svojem prihodu v Moskvo, 4. marca 1518, se je lotil dela: najprej je v enem letu prevedel Novo zavezo s komentarji (1519).

25 Prep. Maksim Grek, Sočinenija, 104.

26 Prep. Maksim Grek, n. d., 110-112.

27 Simoniti, Humanizem na Slovenskem, 24-27.

28 Simoniti, n. d., priloga I, 238-244.

29 Prep. Maksim Grek, n.d., 114. 


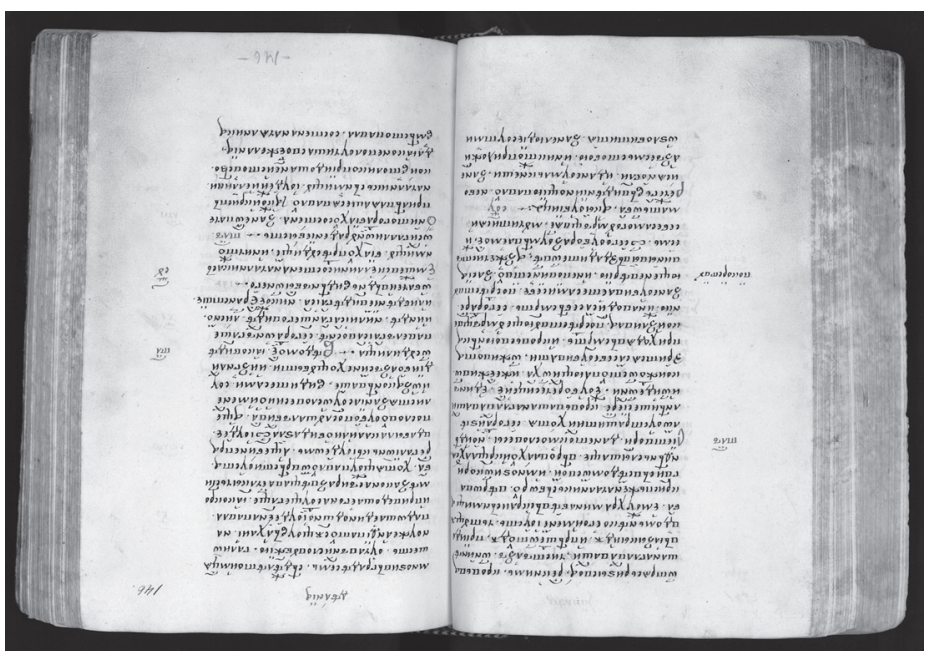

Slika 3: Prevod Nove zaveze (Apostolskih del), rokopis Maksima Greka na marginalijah: Sankt Peterburg, Ruska nacionalna biblioteka (RNB), rok. Kir.-Bel. 24/149, l. 145 v., $146 r$.

Nato se je lotil prevoda Komentiranega Psaltra, ki ga je prevajal leto dni in pet mesecev, kot je povedal v svojem pismu velikemu knezu Vasiliju Ivanoviču, ${ }^{30}$ rokopisna knjiga pa je štela 1042 listov. ${ }^{31}$

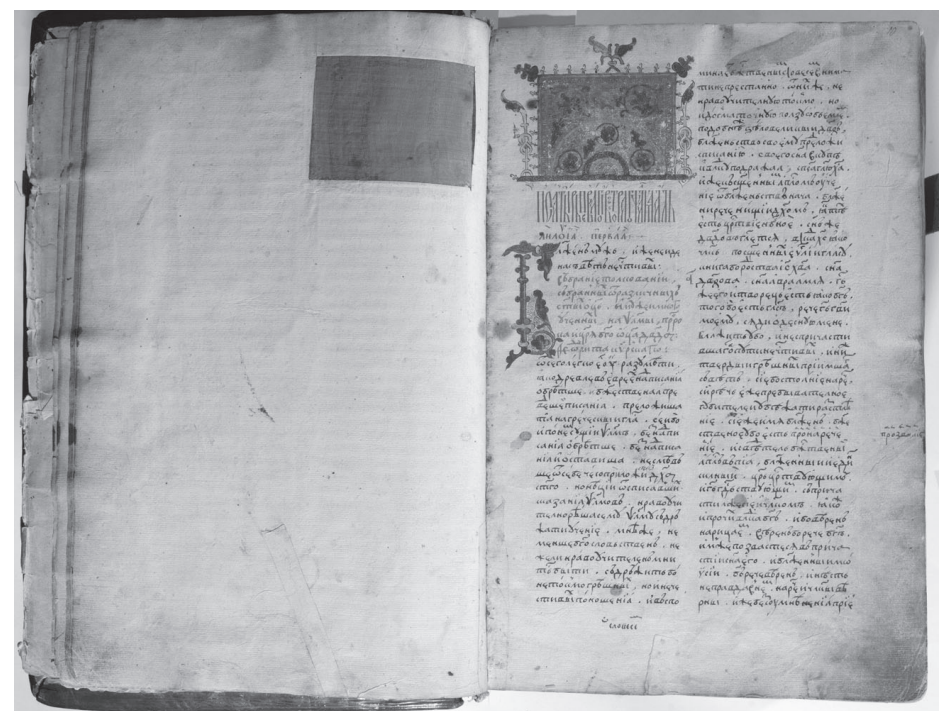

Slika 4: Rokopis Psaltra s komentarji: Moskva, rokopisni oddelek Zgodovinskega muzeja (GIM), rok. Shuk 4, l. o v.

30 Prep. Maksim Grek, Sočinenija, 154.

31 Sinitsyna, Maksim Grek v Rossii, 64-65. 


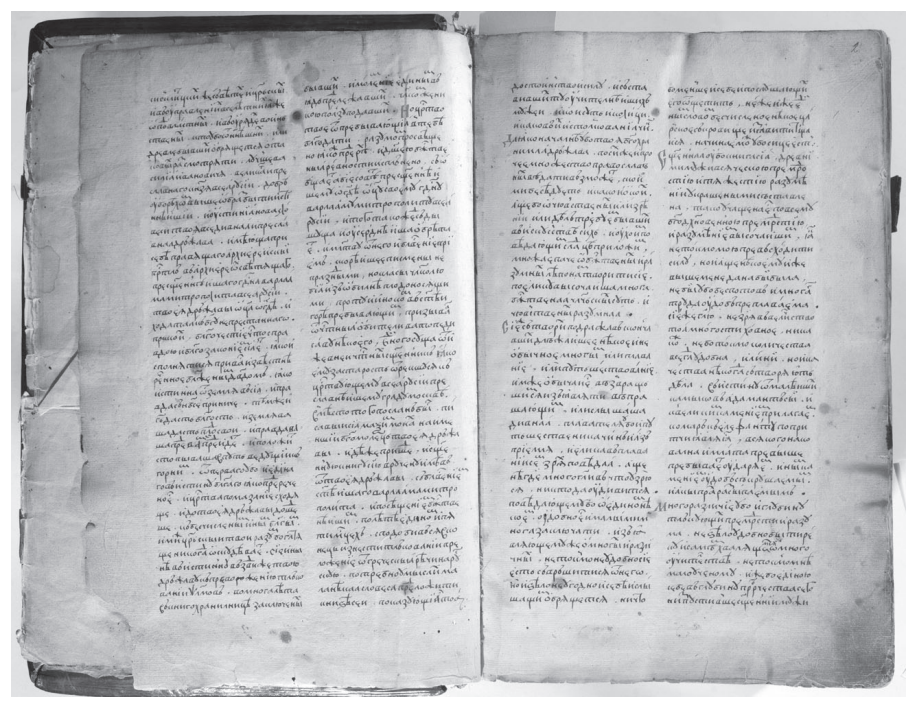

Slika 5: Enako: l. 1v., 2r.

Pri prevajanju sta mu pomagala tolmača Dmitrij Gerasimov in Vlas Ignatov, ki jima je razlagal besedne zveze pogosto v latinščini ter pisarja, menih Silvan ter Mihail Medovarcev. ${ }^{32}$ Pregledoval je tudi bogoslužne knjige v velikoknežji knjižnici in v rokopisih pogosto našel napake. Pogosto je izražal nezadovoljstvo ob spoznanju, da knjige v knjižnici ležijo nedotaknjene in da torej ne služijo svojemu namenu. Knjižnice je namreč razumel kot glavni vir ohranjanja najstarejšega človeškega, ki je vsebovalo tako antično vedenje kot tudi in predvsem krščansko sveto pisanje. Zato je razumljivo, da je z njegovim imenom povezana tudi legenda o znameniti carski (velikoknežji) antični knjižnici, saj je Maksim Grek pisal o zakladih grških knjig, ki naj bi jih le-ta hranila. ${ }^{33} \mathrm{O}$ carski knjižnici je v pismu ruskemu velikemu knezu Vasiliju III. zapisal:

Od prvega in edino resničnega blagra, kot je bilo rečeno, tudi carstvo izhaja in tvojo državo dosega ter $\mathrm{z}$ nepreštevnimi drugimi blagri tvoj um bogati tako, da nikdar ne bo osiromašen. To tudi zdaj tvojo državo resnično vodi $\mathrm{k}$ temu, da bodo psalmi prevedeni in pojasnjeni, saj so bila dolga leta zaklenjeni v hranilnici knjig, kjer so bili hrana moljem in niso z ničemer koristili ljudem. ${ }^{34}$

Maksim Grek je torej izpostavil zaklenjen in nedotaknjen značaj tega trezorja znanja carske biblioteke. Še več, kot se zdi, je želel povedati, da v moskovski Rusiji ni ljudi, ki bi dovolj dobro znali grščino, predvsem pa ne

32 Prep. Maksim Grek, Sočinenija, 165.

33 Več o tem v knjigi S. Belokurov, O biblioteke moskovskih, XXXI.

34 Prep. Maksim Grek, Sočinenija, 153. 
takšnih, ki bi bili kos težavnim lingvističnim analizam bibličnih besedil. Nedvomno je spoznal, da v Moskvi ni veliko ljudi, ki bi zadovoljivo razumeli bistvo pravoslavne teologije. Ko je spregovoril o svojem delu in ljubezni do knjižne modrosti ob prevajanju Komentarjev Psaltra, je knjižnico preimenoval kar v hranilnico vse človeške duhovnosti:

Sveto to knjigo so sestavili stari možje $\mathrm{z}$ vso najvišjo modrostjo in $\mathrm{z}$ vsem okrasom težavnih doumetij /.../ Zato ne pogreši tisti, ki to shrambo, ki ji lahko rečem duhovna, saj je polna različnih milosti, imenuje raj miselni, ki je obogaten $\mathrm{z}$ vrtovi nesmrtnimi, kjer rase cvetje duhovno. V njem ni le različno znanje, ki se izteka obilno, spreobrnjeno v koristno, temveč je tudi teološki ustroj in srž dogem $z$ velikim trudom črpan, saj teologi ne govorijo prav natanko o najvišji in najbolj blaženi Trojici, ampak o tem, kako so se vidne in nevidne reči človekoljubno iz nebivanja $v$ bivanje spremenile, kakor se je pričakovanje prihodnosti obeh (vidnih in nevidnih entitet) v človeškem ustroju zgodilo. ${ }^{35}$

Besedna zveza »vidne in nevidne reči« je vzeta iz osme pesmi liturgičnih hvalnic z naslovom »Pesem treh otrok«, ki so sledile po petju vseh sto petdesetih psalmov v Liturgičnem Psaltru. Slednji je bil brez bil brez komentarjev in ga je Maksim Grek prevedel šele leta 1552, štiri leta pred svojo smrtjo, ko je po skoraj sedemindvajsetih letih spet lahko malce okusil svobodo. Zaradi svojega revizijskega dela z ruskimi rokopisnimi bogoslužnimi knjigami, ob katerem je uporabljal vse svoje prej pridobljeno jezikovno znanje in izkušnje z liturgičnimi rokopisi in prvotiski, je bil obtožen krivoverskih napak pri prevajanju in bil že leta 1525 prvič obsojen na lokalnem moskovskem cerkvenem zboru, leta 1531 pa so se obtožbe proti njemu še podvojile. Natančneje, prvič so ga obtožili neznanja ruskega bogoslužnega jezika, saj je Maksim Grek uporabil dovršni glagol v veroizpovednem obrazcu vere (Credo), čeprav je on le drugače razumel svetopisemsko atemporalnos ${ }^{36}$ ter vztrajal pri strogo teološkem pojmovanju gramatike (v tem pogledu tudi starocerkvenoslovanske). ${ }^{37}$ Poudarjal pa je tudi, da je v ruskih rokopisnih liturgičnih knjigah mnogo napak, ki so posledica njihovega nezadostnega znanja grškega jezika in pravoslavne teologije. Tedaj so ga obsodili na temnico in molk, odvzeli pa so mu tudi možnost pisanja. Leta 1531 so ga obtožili krivoverskih napak pri prevajanju hagiogafskega spisa »Marijino življenje« iz zbirke hagiografij Simeona Logoteta Metafrasta (starocerkveno slovanska različica Menologija, ki ga je Maksim vatopedski na Atosu bral z obširnim ikonografskim gradivom $)^{38}$ ter še nekaterih drugih spornih zadev.

35 Prav tam, $155-156$

36 Več o tem, Zajc, »St Maxim the Greek«, 329-36o.

37 Več o tem, Zajc, "Some Notes«, 375-382.

38 Več o tem, N. P. Sevcenko, Illlustrated Manuscripts of the Metaphrastian Menologion (za ilustrirane ode gl. 11-26, 182, 188-193). 
Zdi se, da je bil vzrok nekaterih novih obtožb tudi njegov prevod pisma papeža Pija II. turškemu sultanu Mehmedu II., ${ }^{39}$ kar govori vprid domnevi, da je menih Maksim imel nemara tesnejše veze $\mathrm{z}$ severnoitalijanskimi intelektualci in filologi, kot se dandanes domneva. V Dunajski narodni knjižnici, kjer hranijo tudi rokopise nekaterih renesančnih veljakov in modrecev, se je šele leta 1986 našel grški rokopis v osebni knjižnici Johannesa Sambucusa, ${ }^{40}$ pod katerega se je podpisal menih Maksim. Ta je leta 1551/1552 iz Moskve poslal dve grški pesnitvi v verzih neznano kam v Evropo. Pismo je naslovil namreč na ljubitelja modrosti po imenu Makrobija, ${ }^{41}$ pri čemer znanstvenikom še ni uspelo dokazati obstoja osebe, ki bi v sredini 16. stoletja nosila to ime ali nadimek. ${ }^{42}$

Resnica je bila, da se Maksim Grek ni strinjal z naraščajočimi težnjami moskovskega patriarhata, da bi se osamosvojil od grške cerkve ter da bi se ustanovila ruska avtokefalna cerkev. Okoli leta $1534 \mathrm{v}$ drugem samostanu svojega priprtja, v Otroč-samostanu v Tveru, so mu kazen ublažili, dobil je priložnost ponovno poprijeti za pisalo. Odtlej je napisal veliko število rokopisnih spisov v stari cerkveni slovanščini. Ohranili so se tudi slovarski osnutki imenskih gesel z vzporednimi termini v stari ruščini, latinščini in grščini. Njegov grški avtograf je identificiran na podlagi njegovega grškega Psaltra $^{43}$ s paralelnimi grško-slovanskimi glosami kanona Marijinemu Oznanjenju, saj je Maksim Grek v tverskem samostanu meniha Benjamina učil grščine.

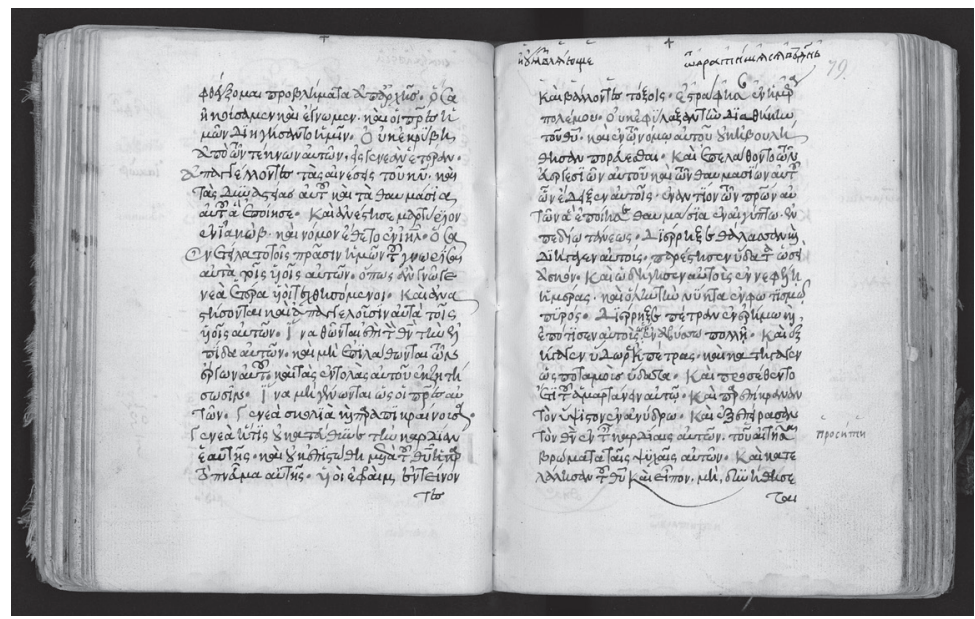

Slika 6: Grški Psalter, slovanske glose Maksima Greka na marginalijah: Sankt Peterburg, Ruska nacionalna biblioteka (RNB), rok. Sof. 78, l. 78 v., l. 79 r.

39 Prep. Maksim Grek, Sočinenija, 522.

40 Več o tem Buškovič, »Maksim Grek, poet-giperboreec«, 215-216.

41 Ševčenko, »On the Greek Poetical Output«, 41.

42 Ševčenko, »On the Greek«, 41, op. 1, 57-58, op. 27; Buškovič, »Maksim Grek«, 217-218.

43 Sinitsyna, Maksim Grekv Rossii, 71. 
Med letoma 1549 in 1552 naj bi postal deloma svoboden, a je bil že zelo star, dobil naj bi pravico do prejemanja obhajila, ki mu je bila odvzeta že na prvem sojenju leta 1525. Umrl je leta 1555/1556 (12. decembra 1555, 21. januarja 1556 je bil na dan sv. Maksima Spoznavalca pokopan) v samostanu Svete Trojice Sergeja Radoneškega v Podmoskovju, še za časa življenja cenjen kot modrec in čaščen kot svetnik.

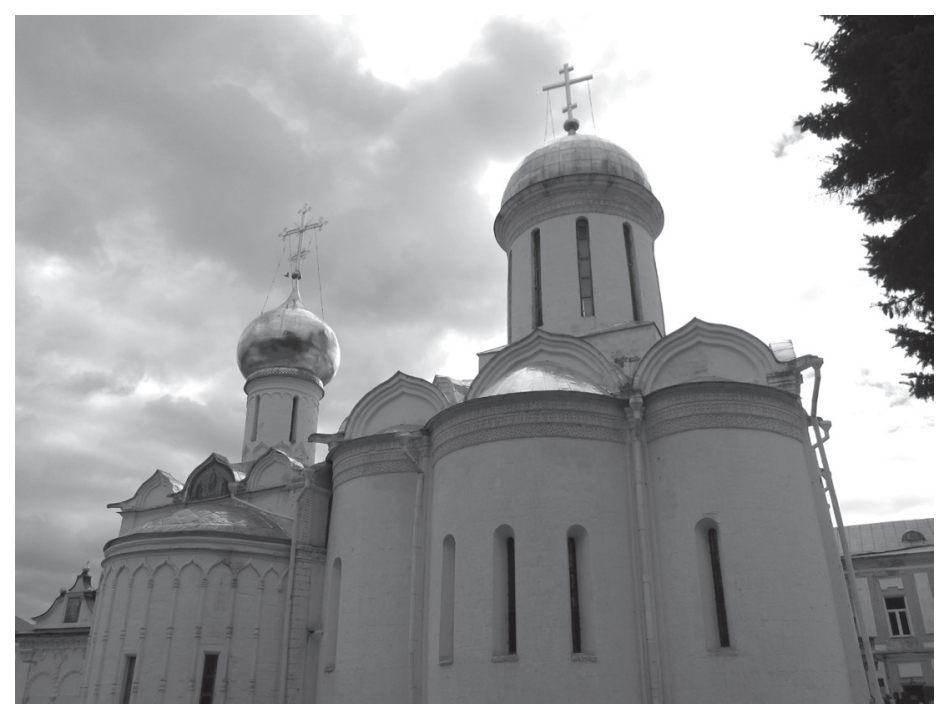

Slika 7: Samostan Svete Trojice Sergeja Radoneškega v Podmoskovju

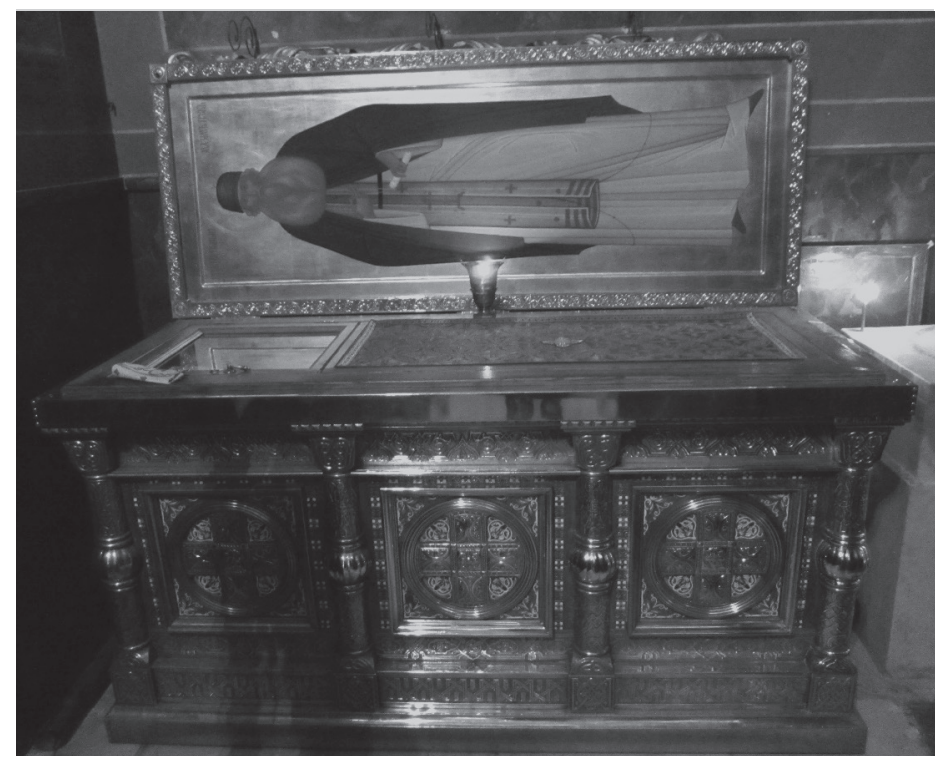

Slika 8: Posmrtni ostanki (relikvije) svetega Maksima Greka 
Z njegovim imenom so v moskovski Rusiji povezovali tudi uvedbo tiska, ki je bil pred Maksimovim prihodom razumljen kot heretična novost. Sam Maksim Grek, ki je ponudil tudi svojo interpretacijo tiskarskega znaka Alda Manuzia, zgolj primerljivo, a ne podobno tisti, ki jo je takrat podal tudi Erazem Rotterdamski, pa je izum tiska razumel v povsem novodobnem pomenu: kot dobrodošlo novost, ki osvobaja od človeške zmotljivosti in svete knjige ohranja v neokrnjeni obliki brez slehernikovih napak. Alda Manuzia se je spominjal kot "pametnega Rimljana«, ki je s sidrom-tiskom vernikovo dušo privedel v željan mir - kakor ladjo med viharji na razburkanem morju. Takole pravi:

V Benetkah je bil neki filozof precej vešč, njegovo ime je bilo Aldus, ${ }^{44}$ vzdevek je bil njegov Manucius, po rodu Frizijec, po očetovi strani je izviral iz Rima, po duhu je bil potomec starega Rima zelo dobro poučen $\mathrm{v}$ rimski in grški pismenosti. Jaz sem ga poznal in videval v Benetkah in sem k njemu pogosto zahajal zaradi knjižnih zadev, čeprav sem bil tedaj mlad in v posvetnih oblekah. Ta Aldus Manucius Rimljan si je v svoji modrosti izmislil tak znak, ki bi s prispodobo opominjal slehernika, gospodarja ali nevedneža, kako bi mogel dobiti večno življenje, če si ga le resnično želi. In s sidrom je upodobil trdnost in moč vere, $\mathrm{z}$ ribo pa - človeško dušo. In s tako prispodobo nas uči in govori: kakor sidro železno krepi in drži ladjo v morju in jo rešuje pred nesrečami vseh morskih valov in neurij, tako tudi strah Božji nehlinjeno in trdo zasidran v dušah človeških v sleherni resnici in resnici zapovedi Božjih - jih rešuje pred vsemi napadi in sovražnosti vidnih in nevidnih sovražnikov. ${ }^{45}$

Šele leta 1580 je bila v Ostrogu prvič natisnjena celotna Biblija v ruski stari cerkveni slovanščini. Zanjo je bil odgovoren tiskar Ivan Fjodorov, ki je bil zaradi svojega poskusa uvajanja tiska na moskovskem dvoru pregnan iz Moskve na obrobje Rusije, v Ostrog. ${ }^{46}$ Res so nekateri znanstveniki poskušali prevod, ki je naveden v Ostroški Bibliji, pripisati že revizijskem delu s svetopisemskim jezikom, kot ga je opravil Maksim Grek. ${ }^{47}$ Enega od zgodnjih izvodov Ostroške Biblije hrani tudi Semeniška knjižnica, v njej pa so na zadnji strani zaznamki v grščini napisanih liturgičnih terminov.

Še za časa življenja je Maksim Grek uredil tri različice svojih (i)zbranih spisov, ki jih je lastnoročno popravljal. In vendar ostaja še vedno skrivnost usode njegovih slovanskih rokopisov: kljub temu, da je bil že osem let po smrti upodobljen na freskah na stenah kremeljske cerkve Marijinega Oznanjenja

44 Aldo Manuzio je bil res rojen kot Teobaldo Manucci (Aldo Manuzio, starejši) leta 145o, šolal se je v Rimu in Ferrari, leta 1482 je spoznal Pica della Mirandolo, leta 1490 je začel delovati kot tiskar, od leta 1494 v Benetkah (Delumeau, La civilization de la Renaissance, 484-485.)

45 Prep. Maksim Grek, Sočinenija, 345-346.

46 Več o tem gl. Kukuškina, Kniga v Rossii, 150-151.

47 Olmsted, "The Ostroh Bible«, Harvard Ukrainian Studies, 115; Prim. Prep. Maksim Grek, Sočinenija, 434. 
kot eden izmed starih modrecev ${ }^{48}$ in je na vseh ikonah upodobljen s pisalom $\mathrm{v}$ roki, $\mathrm{v}$ stroki prevladuje prepričanje, da se med več kot dva tisoč rokopisi, pripisanimi Maksimu Greku, do danes ni ohranil niti en sam spis, ki bi bil napisan $\mathrm{v}$ celoti $\mathrm{z}$ njegovo roko.

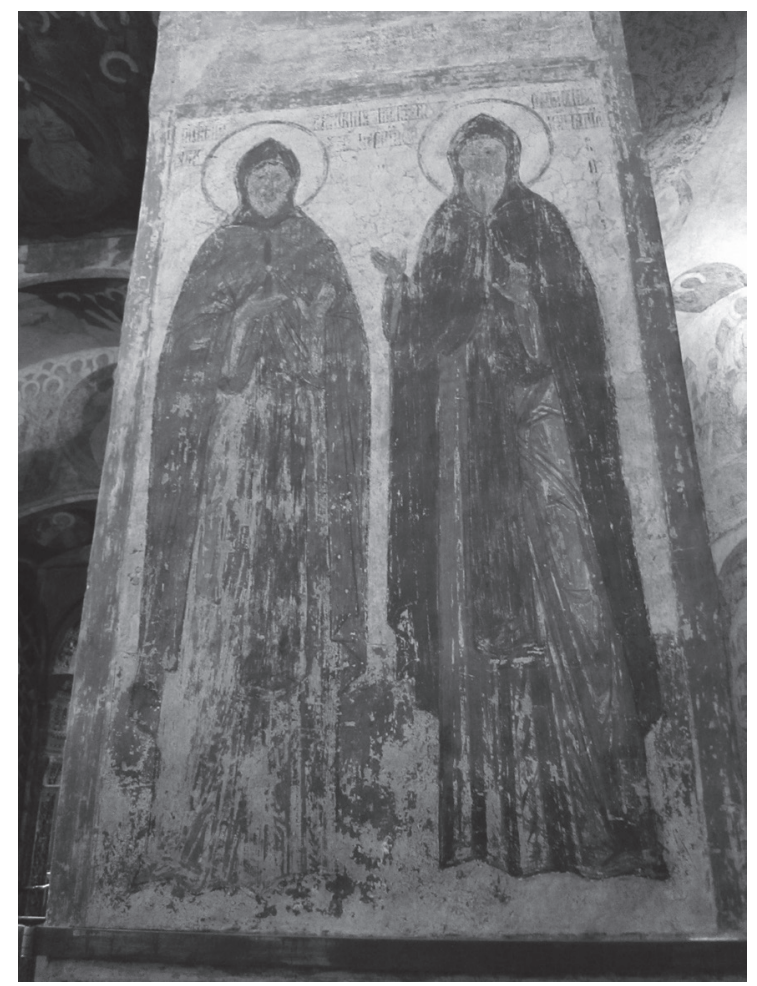

Slika 9: Freska v cerkvi Marijinega Oznanjenja v ansamblu cerkva moskovskega Kremlja ${ }^{49}$

Zabeleženi so le njegovi popravki na marginalijah rokopisov, na podlagi katerih je bil prepoznan njegov slovanski avtograf.

\section{EPILOG}

Morda lahko danes trdimo, da je bil velik pomen dela Maksima Greka tudi v njegovi reviziji liturgičnega jezika cerkvenoslovanskega Psaltra, ki ga je po dvakratni redakciji prečistil dvoumnih izrazov ter uskladil slovanske termine s pravili in mislijo grške pravoslavne teologije. Celotno njegovo duhovno delovanje in pisanje pa potrjuje, da je bila vrednost zgodnjerenesančnih 
knjižnic predvsem v ohranjanju verodostojne vsebine rokopisov v obliki inkunabul in prvotiskov, o čemer priča tudi Oglejski Misal (oglejski obrednik, natisnjen v Benetkah leta 1495 kot Agenda dioecesis Aquilegiensis) v Semeniški knjižnici, s katerim se je v novoustanovljeni ljubljanski škofiji leta 1461/2 vzpostavilo bogoslužje v slovenščini, tedaj šele na pragu renesančnega časa. ${ }^{50}$

\section{BIBLIOGR AFIJA}

Belobrova. O. A. »K voprosu ob ikonografii prep. Maksima Greka.» TODRL 15 (1958): 302-309.

Belokurov, S. A. O biblioteke moskovskih godsudarej v XVI.stoletii. Moskva: Tipografija G. Lissnera i A. Gešelja, 1899.

Buškovič, P. »Maksim Grek - poet-»giperboreec.» Sankt-Peterburg. TODRL 47 (1993): 215-228.

Delumeau, Jean. La civilisation de la Renaissance. Paris: Les Grandes civilisations/ Arthaud, 1984.

Denissoff, Elijah. Maxime le Grec et l'Occident. Contribution à l'histoire de la pensée religieuse et philosophique de Michel Trivolis. Université de Louvain, Recueil de travaux d'histoire et de philologie, $3^{\star}$ série, 14 e fasc. Desclée De Brouwer. Louvain: Bibliothèque de l'Université, 1943.

De Nolhac, Pierre. Les correspondents d'Aldes Manuce, Materiaux nouveaux d'histoire literraire. Studi e documenti di storia e diritto 8. Paris 1887.

Dorez, Leon. »Etudes aldines. I. La marque typographique d'Alde Manuce«. Revue des bibliotheques, 6 (1896): 311-326.

Fonkič, B. L. Grečeskie rukopisi i dokumenti v Rossii v XVI-načale XVIIIv. Moskva: Indrik, 2003.

Garzaniti, Marcello. »Michele Trivolis/Massimo il Greco (1470 circa-1555/1556).« CrSt 36 (2015): 361-366.

Garzaniti, Marcello. Марчелло Гарзанити. Библейские цитаты в церковнославянской книжности. Slavia Christiana. Москва: Индрик, 2014.

Koneski, Blaže. Kniga za Kliment Ohridski. Skopje: Kočo Racin, 1966. Конески, Блаже. Книга за Климент Охридски. Скопје: Кочо Рацин, 1966.

Kukuškina, M. V. Kniga v Rossii v XVI veke. Sank Peterburg: Peterburgsko vostokovedenie, 1999.

Layton, Evro. »Notes on Some Printers and Publishers of $16^{\text {th }}$ century Modern Greek Books in Venice«. Thesaurismata 18 (1981): 119-142.

Legrand, Emile. Bibliographie hellenique ou description raisonnes des ouvrages publies en grec par des Grecs aux XVe et XVe siecles. Paris, 1885.

Oikonomidès, Nicolas. Actes de Kastamonitou. Archives de l'Athos 9. Paris: P. Lethielleux, 1978.

Olmsted, Н. in M. Taube. »Повесть о Есфири,The Ostroh Bible and Maksim Grek's Translation of the Book of Esther." Harvard Ukrainian Studies 11 (1987): 100-117.

Piccolomini, Enea. »Aggiunte e rettificazioni all'articolo Due documenti intorno ad acquisti di codici greci fatti da Giovanni Lascaris per conto di Lorenzo de' Medici«.

50 Prispevek je nastal v okviru izpolnjevanja programa P6-0o94 (A), ki ga iz proračunskih sredstev Republike Slovenije financira ARRS. 
Revista di filologia e d'instruzione classica 3 (1875): 150-152.

Renouard, Antoine Augustin. Annales de l'imprimerie des Alde ou Histoire des trois Manuce et de leurs editions. 3. izdaja. Paris, 1834.

Sevcenko, Nancy. P. Illlustrated Manuscripts of the Metaphrastian Menologion. Chicago: University of Chicago Press, 1990.

Speranzi, David. »Michele Trivoli e Giano Lascari. Appunti su copisti e manoscritti greci tra Corfù e Firenze«. Studi Slavistici 7 (2010): 263-297.

Schmitt, C. B. Gianfrancesco Pico della Mirandola (1469-1533) and his Critique of Aristotle. The Hague: Martinus Nijhof, 1967.

Sinicyna, N. V. Maksim Grek v Rossii. Moskva: Nauka, 1977. Синицына, Н. В. Максим Грек в России. Москва: Наука, 1977.

Prep. Maksim Grek, Sočinenija: Преп. Максим Грек. Сочинения. Том 1. Uvod, spremna študija, opombe, urejanje N. V. Sinitsyna, Н. В. Синицына. Москва: Индрик, 2008.

Simoniti, Primož. Humanizem na Slovenskem. Ljubljana: Slovenska matica, 1979.

Ševčenko, Ihor. »The Four Worlds and the Two Puzzles of Maksim the Greek«. Paleoslavica 19, št. 2 (2011): 294-304.

Ševčenko, Ihor. »On the Greek Poetic Output of Maksim Grek«. Byzantinoslavica 58 (1997): 1-60.

Zajc, Neža. »St Maxim the Greek (Преп. Максим Грек, 1470-1556): Some Notes on His Understanding of the Sacred Time«. Slavia Meridionalis 16 (2016): 329-360.

Zajc, Neža. »Some Notes on the Life and Works of Maxim the Greek (Michael Trivolis, ca 1470 - Maksim Grek, 1555/1556). Part 2: Maxim the Greek's Slavic Idiolect.» Scrinium 12 (2016): 375-382. 